\title{
METHODS FOR CONTROL THE SELF-SUSTAINED PLASMA-BEAM DISCHARGE AT HIGH ENERGY DENSITY
}

\author{
Ya.O. Hrechko, N.A. Azarenkov, A.F. Tseluyko, D.L. Ryabchikov, I.N. Sereda \\ V.N. Karazin Kharkiv National University, Kharkiv, Ukraine \\ E-mail: yarikgrechko18@gmail.com
}

Three methods for control the self-sustained plasma-beam discharge at high energy density are presented in this paper. Using a particular method, it is possible to set the location of the double layers formation in the discharge gap, as well as control its parameters at the high-current inductive discharge stage. It is shown that such methods can significantly increase the active power inputted into the discharge.

PACS: 52.58.Lq, 52.59.Mv

\section{INTRODUCTION}

Self-sustained plasma-beam discharge (SPBD) is a special form of a self-sustained gas discharge, since it allows to obtain levels of power in the discharge up to tens and hundreds of gigawatts. At the discharge currents from hundreds of amperes to megaamperes, the discharge voltage can reach hundreds of volts to hundreds of kilovolts. The SPBD was first described in paper [1]. The transition from the arc discharge to the SPBD occurs under conditions when the currentcarrying discharge plasma can't transfer all the current that the power source provides. In this case, a double electric layer of space charge is formed in the plasma. Almost all active discharge voltage is concentrated on it [2]. Counter acceleration of electron and ion beams occurs in electric field of the double layer. The beam current is determined by plasma parameters, since the double layer thickness is much less than the discharge gap length. The main energy contribution to the discharge is provided by the electron beam, which begins to give up its energy immediately beyond the acceleration zone [3]. The energy dissipation distance is comparable to the double layer thickness. Under this approach, the local energy input into the discharge is provided with a power density of up to $10^{9} \mathrm{~W} / \mathrm{cm}^{2}$ and higher.

By controlling the double layer location it is possible to form the electron beam directly in front of the object, where energy input is supposed (plasma, solid, other objects). For example, the fast energy input with a high power density into a plasma of multiply ionized tin atoms makes it possible to generate powerful (megawatts and higher) directional EUV-radiation with wavelength of $13.5 \mathrm{~nm}$ from such plasma [4]. Intensive effects on a solids surface at such power densities can significantly modify the materials surface layer, giving them unique properties [5]. Thus, it is relevant to search the methods for control the SPBD at high energy density, namely, the location of the double layer formation, as well as its parameters (energy and beam current), to stabilize the discharge and increase the power inputted into the discharge.

\section{EXPERIMENTAL SETUP}

The SPBD mode at high energy density was realized using a high-current pulsed plasma diode. Fig. 1 shows a schematic representation of the plasma diode discharge cell.

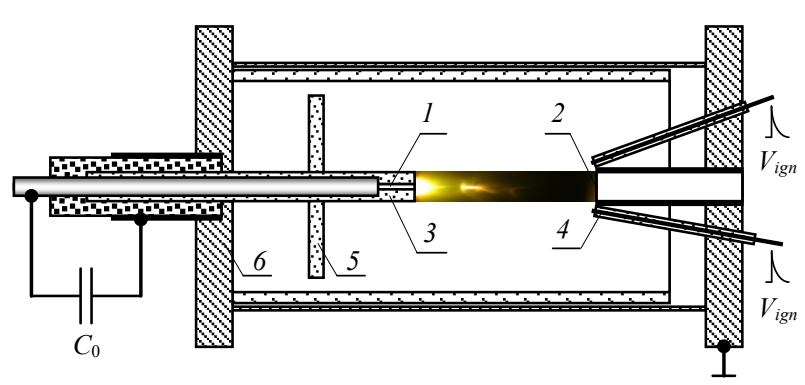

Fig. 1. Schematic representation of the plasma diode discharge cell

The diode includes a high-voltage rod 1 and a grounded tubular 2 electrodes, which are located opposite each other at a distance of $5 \mathrm{~cm}$. The diode distinctive feature is the limitation of the high-voltage electrode working surface by the ceramic tubular insulator 3 , so that only the electrode end is remained as the working surface. The working surface area of the highvoltage electrode varies within $S_{a} \sim 0.02 \ldots 0.2 \mathrm{~cm}^{2}$, and is much smaller (two orders of magnitude) than the working surface of the grounded electrode. This makes it possible to concentrate a current of high density on the high-voltage working surface, and contributes to the double layer formation near it.

The high-voltage electrode is directly connected to a capacitor bank, with a capacity of $C_{0}=1.914 \mu \mathrm{F}$, which is charged to a voltage of $V_{0}=6 \ldots 12 \mathrm{kV}$. The discharge is excited at a low pressure of $\sim 10^{-6}$ Torr after filling the discharge gap with the primary plasma, which is created due to surface breakdown between the grounded electrode and the ignition electrodes 4 . The primary plasma electrons, accelerating in the double layer near the high-voltage electrode, irradiate the electrode working surface. This leads to its heating, surface evaporation, vapor ionization and the formation of dense $\left(\sim 10^{16} \ldots 10^{17} \mathrm{~cm}^{-3}\right)$ near-electrode plasma. To exclude the dense plasma spread along the insulator 3 in the direction of the holding flange 6 , the insulator has a disk ceramic crest 5 . As soon as the discharge active resistance becomes less than twice the wave resistance, the discharge passes into a high-current inductive stage with current amplitude of up to $40 \mathrm{kA}$ and a current oscillation period of $\sim 3.5 \mu \mathrm{s}$.

Since the beginning of the high-current stage, the double layer near the high-voltage electrode disappears, but other double layers periodically appear and disappear, changing their localization and the magnitude of the potential drop. The double layer formation provides 
additional energy input into the discharge. Fig. 2 shows an enlarged image of the discharge gap $(a)$ with characteristic zones of energy absorption. The photo of the discharge gap was made using a system of high-speed photo registration in the visible wavelength range. Below is the current waveform $(b)$, which shows the characteristic time moments corresponding to the energy absorption zones. Discharge current measurement was carried out using an inductive current sensor. The current signal was recorded with a digital oscilloscope Tektronix TDS2014.
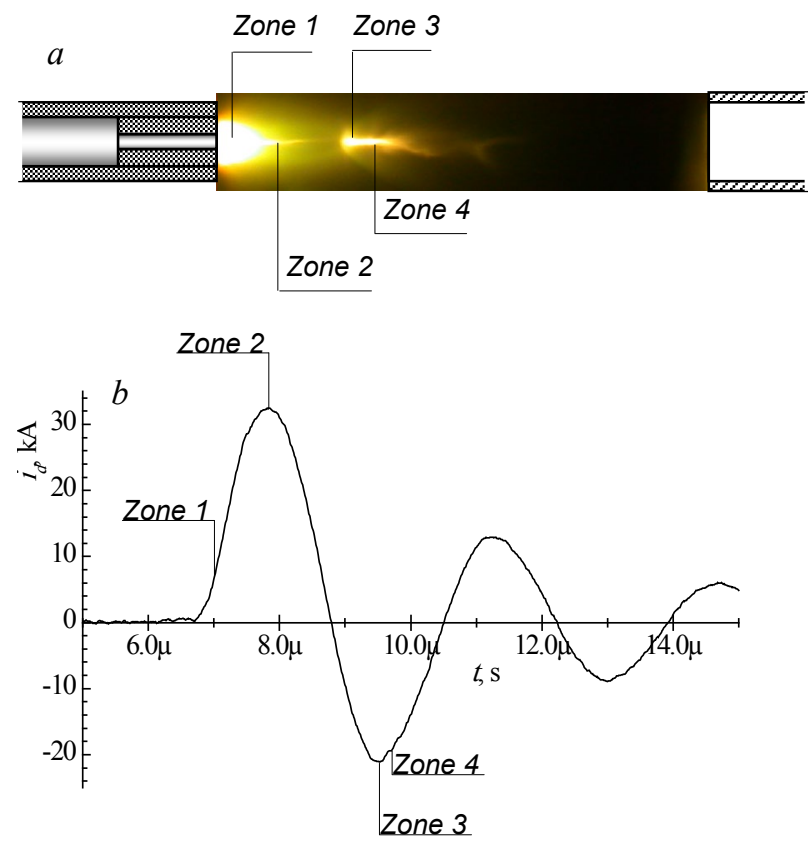

Fig. 2. Enlarged image of the discharge gap (a) and current waveform (b) with characteristic zones of energy absorption

\section{RESULTS AND DISCUSSIONS}

To control the double layers location at the highcurrent discharge stage and increase the power inputted into the discharge, the following methods were used: reduction of the high-voltage electrode working surface, partial contraction of the current channel by a dielectric capillary, effect of the external constant magnetic field. The efficiency of a particular method was determined by the dynamics of the discharge active power and the amount of energy released in the discharge. The calculation of the discharge active power was carried out according to the method presented in paper [6].

\subsection{REDUCTION OF THE HIGH-VOLTAGE ELECTRODE WORKING SURFACE}

To study the effect of the high-voltage electrode working surface area on the discharge dynamics and the level of active power inputted into the discharge, electrodes with a diameter of 5, 2.5, and $1.5 \mathrm{~mm}$ were used. Fig. 3 shows the dynamics of active power inputted into the discharge at different high-voltage electrode diameters. This time dependence is obtained at the charging voltage $V_{0} \sim 12 \mathrm{kV}$. It can be seen that the level of active power inputted into the discharge increases as the high-voltage electrode diameter decreases. When the electrode diameter decreases from 5 to $1.5 \mathrm{~mm}$, the discharge active power increases from $\sim 60$ to $90 \mathrm{MW}$ (at the discharge current maximum). Due to the limited working surface of the high-voltage electrode, the maximum power density released at the electrode significantly increases from $\sim 0.3$ to $5 \mathrm{GW} / \mathrm{cm}^{2}$. It should be noted that the main part (up to $70 \%$ ) of energy is released in the $1^{\text {st }}$ half-period of the discharge current oscillation. Therefore, further comparison of the energy released in the discharge will be presented only for the $1^{\text {st }}$ half-period.

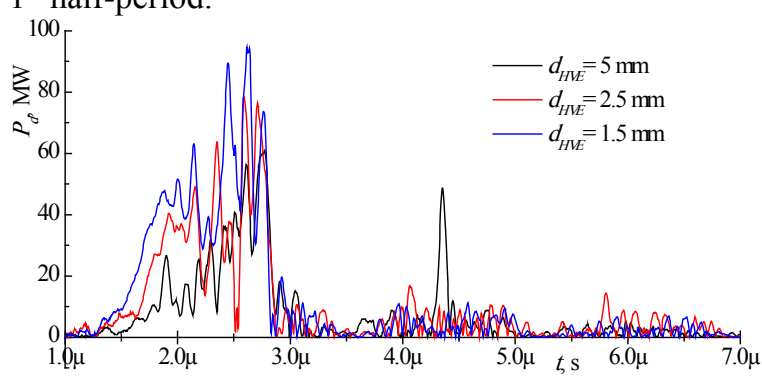

Fig. 3. Dynamics of active power inputted into the discharge at different high-voltage electrode diameters

Fig. 4 shows the dependence of the maximum value of the discharge current $(a)$ and the energy released in the $1^{\text {st }}$ half-period $(b)$ on the stored energy of the capacitor bank for different electrode diameters. One can see that in the whole range of given stored energy values, with a electrode diameter decrease, there is a slight (on average by $10 \%$ ) decrease in discharge current and a significant (by $60 \ldots 80 \%$ ) increase in energy released in the discharge.
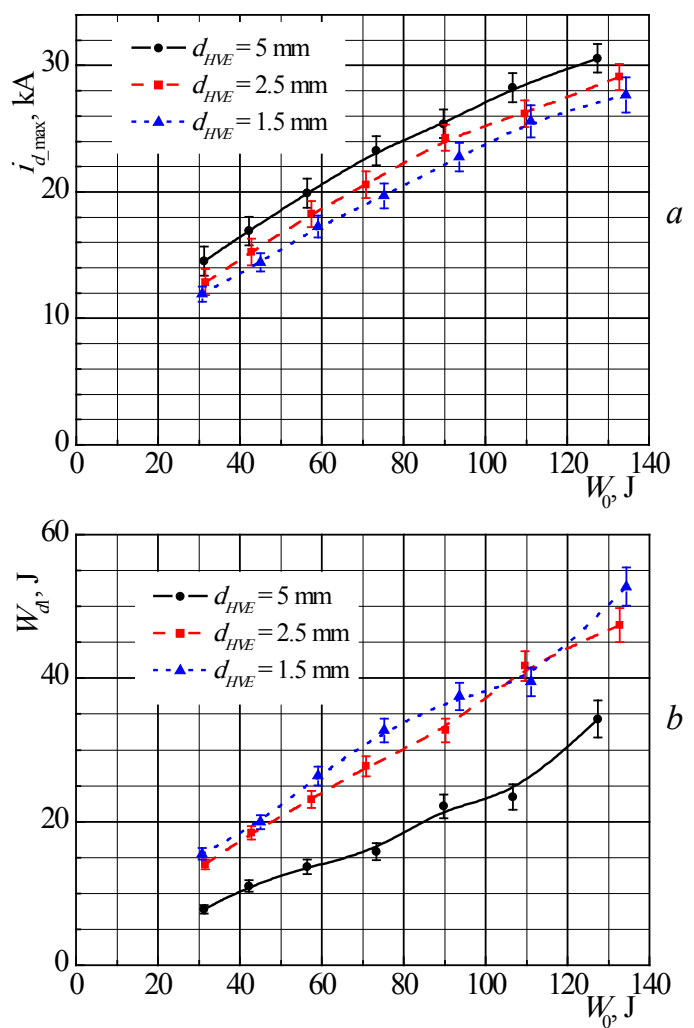

Fig. 4. Dependence of the maximum discharge current (a) and the energy released in the $1^{\text {st }}$ half-period (b) on the stored energy of the capacitor bank 


\subsection{PARTIAL CONTRACTION OF THE CURRENT CHANNEL}

Partial contraction of the current channel was carried out using a dielectric insert, which was placed in the discharge gap between the diode electrodes. The insert was a glass beaker with a hole in the center with a diameter of $2 \mathrm{~mm}$. The insert hole defined a dielectric channel $5 \mathrm{~mm}$ long, similar to a capillary. The optimum distance from the high-voltage electrode end to the insert hole $\sim 5 \mathrm{~mm}$ was experimentally determined. At this distance the stable discharge excitation from pulse to pulse was noted.

Fig. 5 shows the dependence of the maximum value of the discharge current $(a)$ and the energy released in the $1^{\text {st }}$ half-period $(b)$ on the stored energy of the capacitor bank in the case of contracted (solid line) and noncontracted (dotted line) system. One can see that in the whole range of given stored energy values, the discharge current in the case of contracted system is on average by $9 \ldots 10 \%$ less than in the non-contracted case, and the energy released in the discharge, on average, $40 \%$ more. The increase in the energy released in the discharge apparently due to the formation of an additional double layer near the dielectric insert hole. This is due to the fact that the double layer is formed in the place where the current transfer by the plasma is most difficult. In contracted system the current of the power source must be 2-3 times greater than the current that plasma can pass through the dielectric channel.
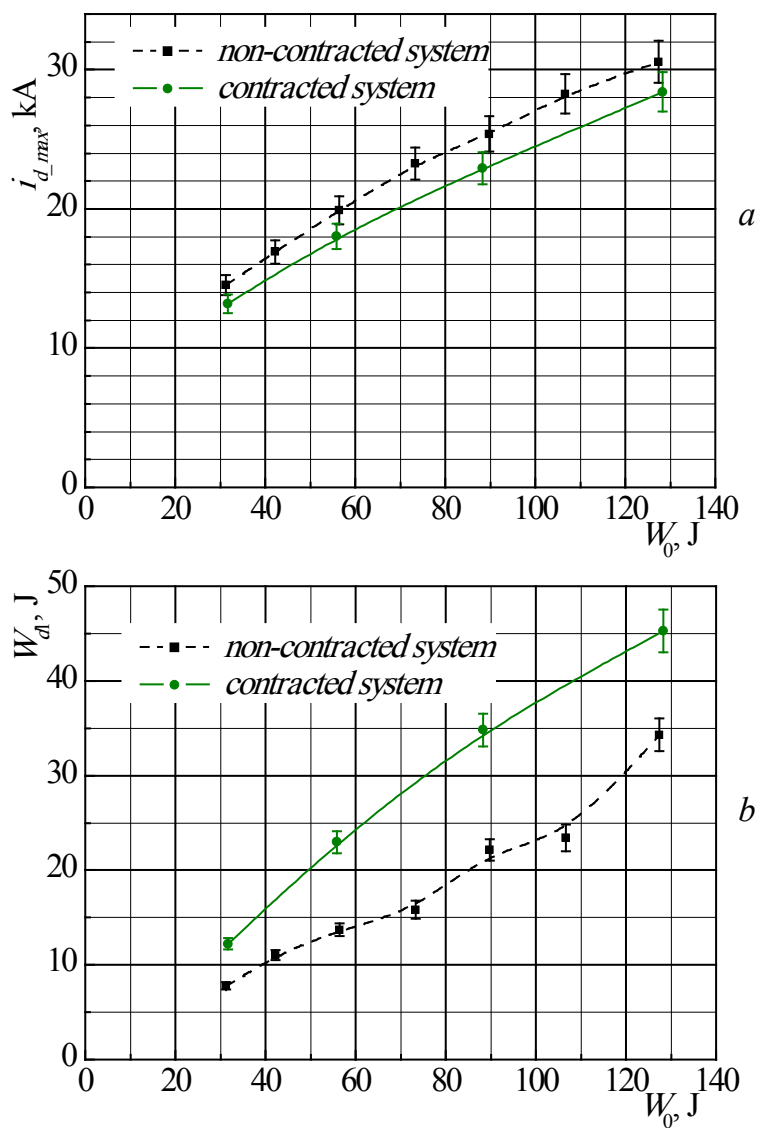

Fig. 5. Dependence of the maximum discharge current

(a) and the energy released in the $1^{\text {st }}$ half-period (b) on the stored energy of the capacitor bank

\subsection{EFFECT OF THE EXTERNAL CONSTANT MAGNETIC FIELD}

An external magnetic field was created by a system with two permanent ring magnets. The choice of ring magnets was due to their peculiarity, namely the presence of an inversion point, which arises due to a split magnetic field fluxes. Such distribution of magnetic fluxes creates a magnetic trap and magnetic barriers for the plasma.

The experiments were carried out for four positions of the magnetic system relative to the high-voltage electrode end (Fig. 6). In the first case, the electrode end was located in the region with minimum magnetic field $\left|B_{\min }\right|=0.235 \mathrm{kG}$, in the second case - in the magnetic field inversion point $B_{i n v}=0$, in the third case - in the intermediate point with magnetic induction $B_{z} \sim 0.64 \mathrm{kG}$ (the electrode end coincided with the magnetic assembly end), in the fourth case - in the region of the maximum magnetic field $B_{\max }=1.1 \mathrm{kG}$ (in the center of the magnetic assembly) [7].

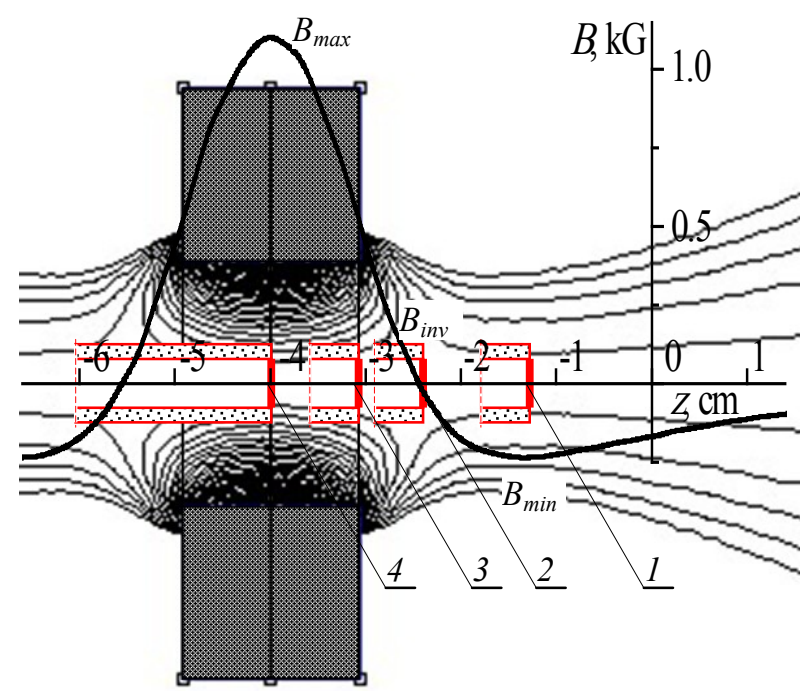

Fig. 6. Magnetic field topology and the induction distribution on the discharge axis for magnetic system with two permanent ring magnets [7]

Since the intensity of the discharge intrinsic magnetic field at the high-current inductive stage could reach up to $\sim 100 \mathrm{kOe}$, such an external magnetic field affected only at the initial discharge stage. In this case, such a topology of the primary plasma was formed, which set a further scenario of the discharge passing at the highcurrent stage with a given place of double layers formation and its parameters.

Fig. 7 shows the dependence of the maximum current ratios $(a)$ and ratios of energies released in the $1^{\text {st }}$ half-period $(b)$ on the stored energy for different positions of the magnetic assembly in comparison with the discharge without an external magnetic field. It can be seen that for all positions of the magnetic assembly, the discharge current decreases in the presence of an external magnetic field and the energy released in the discharge increases. At stored energy up to $90 \mathrm{~J}$ the greatest increase in energy is observed for the case when the high-voltage electrode end is located in the magnetic field minimum. Above $90 \mathrm{~J}-$ in the magnetic field in- 
version point. Apparently, due to diamagnetism, the primary low-temperature plasma is forced out into the region with a smaller magnetic field, and concentrates near the magnetic field inversion point.
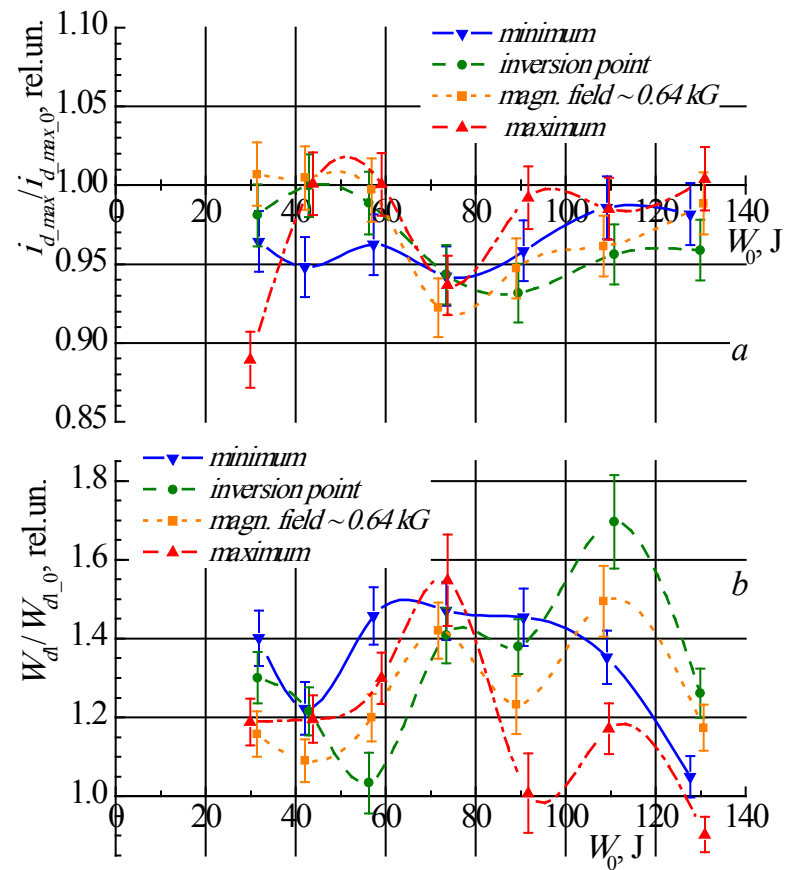

Fig. 7. Dependence of the maximum current ratios (a) and ratios of energies released in the 1st half-period (b) on the stored energy for different positions of the magnetic assembly in comparison with the discharge without an external magnetic field

\section{CONCLUSIONS}

Thus, it has been shown that given methods for control the self-sustained plasma-beam discharge at high energy density influence on the discharge dynamics and the active power inputted into the discharge. For all three methods, an increase in the active power inputted into the discharge is observed against the background of decrease in the discharge current, which, apparently, is related to decrease in the size of the current channel. Reducing the current-carrying abilities of the plasma leads to an increase in the discharge active resistance and the formation of double layers in the plasma, which provide additional energy input into the discharge.

\section{REFERENCES}

1. E.I. Lutsenko, N.D. Sereda, A.F. Tseluyko. Selfsustained plasma-beam discharge // Letters to Journal of Technical Physics. 1987, v. 13, № 5, p. 294298.

2. E.I. Lutsenko, N.D. Sereda, A.F. Tseluyko. Dynamic double layers in high-current plasma diodes // Journal of Technical Physics. 1988, v. 58, № 7, p. 12991309.

3. L.P. Block. A double layer review // Astrophysics and Space Science. 1978, v. 55, Issue 1, p. 55-83.

4. A.F. Tseluyko et al. Experimental study of radiation in the wavelength range $12.2 \ldots 15.8 \mathrm{~nm}$ from a pulsed high-current plasma diode // Plasma Physics Reports. 2008, v. 34, Issue 11, p. 963-968.

5. A.Ya. Leyvi et al. Modification of the constructional materials with the intensive charged particle beams and plasma flows // Bulletin of the South Ural State University. Ser. Mechanical Engineering Industry. 2016, v. 16, № 1, p. 28-55.

6. Ya.O. Hrechko et al. Features of active power definition in high-current pulsed discharge // Problems of Atomic Science and Technology. Series "Plasma Physics”. 2016, № 6, p. 48-51.

7. Ya.O. Hrechko et al. Effect of the external magnetic field on the dynamics and power of the selfsustained plasma-beam discharge // Problems of Atomic Science and Technology. Series "Plasma Physics”. 2018, № 6, p. 198-201.

Article received 04.06.2019

\section{МЕТОДЫ УПРАВЛЕНИЯ САМОСТОЯТЕЛЬНЫМ ПЛАЗМЕННО-ПУЧКОВЫМ РАЗРЯДОМ ПРИ ВЫСОКОЙ ПЛОТНОСТИ ЭНЕРГИИ}

\section{Я.О. Гречко, Н.А. Азаренков, А.Ф. Целуйко, Д.Л. Рябчиков, И.Н. Середа}

Приведены три метода управления самостоятельным плазменно-пучковым разрядом при высокой плотности энергии. Используя определенный метод, можно задавать местоположение формирования двойных слоев в разрядном промежутке, а также управлять его параметрами на сильноточной индуктивной стадии разряда. Показано, что приведенные методы позволяют значительно увеличить активную мощность, вводимую в разряд.

\section{МЕТОДИ КЕРУВАННЯ САМОСТІЙНИМ ПЛАЗМОВО-ПУЧКОВИМ РОЗРЯДОМ ПРИ ВИСОКІЙ ГУСТИНІ ЕНЕРГІї}

\section{Я.О. Гречко, М.О. Азарснков, О.Ф. Целуйко, Д.Л. Рябчіков, І.М. Середа}

Наведено три методи керування самостійним плазмово-пучковим розрядом при високій густині енергії. Використовуючи певний метод, можна задавати розташування формування подвійних шарів у розрядному проміжку, а також керувати його параметрами на сильнострумовій індуктивній стадії розряду. Показано, що наведені методи дозволяють значно збільшити активну потужність, що вводиться в розряд. 